思われる。このため臨床では，それぞれの膜厚を考慮 したいわゆる生物学的強さで検討する必要がある. 膜 迷路各部位においてそれぞれの膜厚はそれぞれの曲率 半径に比較して十分薄いため,ここで薄膜応力理論を 適用する，I）円筒形に変形すると仮定した場合（二 軸固定) ( $\mathrm{p}=$ 内圧, $\rho=$ 曲率半径, $\mathrm{t}=$ 膜圧)

軸方向の応力: $\sigma_{l}=\frac{\mathrm{p} \rho}{2 \mathrm{t}}$

円周方向の応力: $\sigma \theta=\frac{\mathrm{p} \rho}{\mathrm{t}}$

となり(1)式は(2)式の 2 倍の応力を生ずる。したがって 均一な強度の材料だとすると, 円周方向に破断し, 龟 裂は軸方向に走ることになる，II）球形に変形すると 仮定した場合（全周固定）

$$
\text { 等二軸 応力: } \sigma=\frac{\mathrm{p} \rho}{2 \mathrm{t}}
$$

すなわち(1)式と同じ形になる.この理論を用い，半規
管とライスネル膜は円筒形の変形，球形蕒膜と卵形 膜は球形の変形をすると仮定した，そのうえて膜迷路 各部位の耐内圧值を $\mathrm{mmHg}$ 単位で示すと，半规管 $3288-440 \mathrm{mmHg}$ ・卵形童膜 $236-79 \mathrm{mmHg} ・$ ライネ 儿膜 $102-41 \mathrm{mmHg} \cdot$ 球形賈膜 $52-17 \mathrm{mmHg}$ となっ た。 以上よりヒ卜膜迷路では pars superiorに比較し pars inferior の方が力学的に弱く，そのために膜迷路 全体に内リンパ圧上昇（内・外リンパ压差の搪大） 。 しくは内リンパ液増量などの病変が生じても, 水腫が 力学的に弱い pars inferior に限局する可能性が示さ れた。またこの病変に要する圧力は微小であり，ヒト 血圧では毛細血管圧一細胞脈圧でよいことが示され た。質問 大谷 嚴(福島医大)。ライスネル膜の 力学的強度に回転差はなかったか。応答 まだ2 耳の測定でライスネル膜の部位別強度については検討 していない.

\title{
47. 染色体異常における側頭骨病理所見
}

佐古雅子（大手前）佐野光仁（富田林）原田 保・阪上雅史・松永 亨 (阪大) 中山雅弘（大阪母子医療センター・病理）

18 トリソミ -2 例と, No. 1 染色体の長腕に他の染 色体の一節が余分に付着した，部分的トリソミーであ る1qトリソミー，及び性染色体のモノソミーである Turner 症候群の側頭骨病理について報告した。

(症例 1:18トリソミー) 在胎37週に帝王切開にて出 生した男児で小耳症, 小下顎症, clenched hand, rocker bottom foot, short first toes, 顔貌異常等の 外表奇形があり18トリソミーが疑われた. 生後 3 日目 に次第に呼吸困難が增強し死亡. 側頭骨では, 顔面神 経が第一膝部において鈍角に走行し，短蝸牛（約 1 回 転半）が認められた。蝸牛軸, 血管条, コルチ器は正 常だった。右側では，アブミ骨前脚の形成不全と底板 の固着が見られ，後脚も底板の中心ょりに付着してい た。また左側ではアプミ骨頭部に変形が見られた。

（症例 2:18トリソミ一）在胎37週にて出生した女児 で，心エコーにて両大血管右室起始症が諗められた。 心不全徵候が次第に強まり生後 8 日目に死亡. clenched hand, short first toes 以外は外表奇形は少なく, 染色体分析にて18トリソミーが確認された。側頭骨で は utricular endolymphatic valve $の$ 欠損と, 球形慗膜 が虚脱し感覚細胞上に異常な膜梾物を形成しているの
が認められた．その他，一例目と同様に顔面神経の第 一滕部における鈍角走行が認められた。

(症例 3:1qトリソミー) 在胎29週にて帝王切開に より出生した女児で, 母親は41歳の高齢初産婦だった。 耳介の下方付着, 高く狭い口蓋, 胸郭の拡張, rocker bottom foo, clenched hand 等が見られた。全身状態 が徐々に悪化し生後 5 日目に死亡. 染色体分析にて, 一番の染色体の長腕に過剩バンドが認められた。側頭 骨では螖牛小管がやや拡大し，蝸牛回転数は 2 回転弱 しか認めなかった。また，ラセン神経節細胞が減少し， 内リンパ管, 内リンパ裹の拡大が見られた。

(症例 4: Turner 症候群) 36歳経産婦の第 2 子で, 在 胎19週にて死産. 第 1 子も死産だった。染色体分析に て 45XO が確認され, Turner 症候群と診断された。後 缅部に巨大なリンパ霊胞を伴い, 左心の形成不全, 大 動脈縮窄症等の心奇形と, 内性器の軽度低形成が見ら れた。側頭骨ではアブミ骨の形成不全が認められた。 質問 大谷 嚴(福島医大)。染色体異常による側頭骨 奇形に共通点はなかったか. 応答 今後, 症例を 集め検討したい。

\section{Alport 症候群の側頭骨病理所見}

\author{
小針仁美・大谷 厳・安斎友博（福島医大）
}

臨床的に Alport 症候群の診断で, 慢性腎不全のた

め 4 年間透析療法を受けた症例の側頭骨病理所見につ 
いて，検討する機会を得たので報告した。

症例梳36䁍の性，家族歴として母親に高血圧症が あり，また本人も含めて同胞 6 名中男性 4 名のす心゙て に腎不全を有している，20歳ごろより蛋白尿を指摘さ れ，32歳ごろより慢性腎不全のため人工透析を受けて いた. 昭和61年 8 月 3 日, 突然に左眼窝部痛, 頭痛が 出現し, 脳動脈瘤破裂の診断で翌 4 日に手術が行われ たが，術後に肺炎を併発し，11月 2 日死しした。昭和 57 年 6 月 11 日の純音聴力検査では, $8 \mathrm{kHz}$ で右 $30 \mathrm{~dB}$, 左 40dBの聴力レベルで他は正常範囲内であった。主 な病理解剖所見は脳動脈瘤破裂, 慢性腎不全, 心肥大, 出血傾向, 全身諸蔵器の著明な息等であった。

側頭骨は死後2.5時間で採取され, Heidenhain$\mathrm{SuSa}$ 液にて固定後, 常法に従って脱灰脱水し, ツエロ イジン包埋後, $25 \mu$ の厚さで水平断連続切片を作製し て10枚ごとに H-E染色を施し, 光学䫒微鏡で観祭し た，所見は左右ともほほ同じであった，外耳道，鼓膜， 耳小骨の形態に異常は見られず，中耳腔，中耳粘膜は きれいで，炎症の所見はみられない，骨迷路には形態 的異常はない, 蝸牛は 2 回転半で蝸牛管の長さは右 $31.6 \mathrm{~mm}$, 左 $31.1 \mathrm{~mm}$ で異常ない. 内リンパ, 外リン パ腔は清澄で出血は認められない. ライスネル膜は軽 度虚脱しているがコルチ器は良く保たれており, 内， 外有毛細胞はほほ正常で変性，消失などの所見はみら
れない，血管条には萎縮，変性はみられない。ラセン 神経節には著変なく，その数と分布はほぼ正常と思わ れる.ラセン勒帯は萎縮性で多数の空㭞が認められる. 右基底回転，左側中回転に血管条とラセン靶帯の境界 部に好塩基性の沈着物が認められる。前庭には特に異 常を認めず, 平衡班の感党上皮細胞も良く保たれてお り，特に異常は認められない。

Alport 症候群の側頭骨病理の異常所見として現在 までに報告されている主なものは，有毛細胞の変性， 萎縮, ラセン神経節細胞の減少, 消失, 血管条の変性, ラセン靯帯の萎縮, 空胞状変性, 血管条とラセン鞀帯 の塩基性沈着物等であり，本例においてはラセン䩗带 の空胞状変性とラセン靶带と血管条の境界部の塩基性 讴着物が認められた。塭基性の沈着物については透析 患者の側頭骨にもみられることが報告されており，血 中のリン酸カルシウムの上昇のためと推測されてい る. ラセン靶带の萎縮, 空胞状変性は本症候群の多く の側頭骨で認められているが，内耳液の循謤動態に関 わる部位であるだけに難聴の成因との関わりが興味深 い. 本症候群の側頭骨病理について検討する際には長 期間の人工透析や，耳性薬偊，加齢などの影響も考 慮に入れる必要があり，今後さらに電影レバル，ある いは生化学的な検索が期待される。

\section{9. 側頭骨 fibrous dysplasia の 2 症例}

\section{川島 理 - 川島秀夫 - 伊藤文英 - 龟井民雄（群大）}

側頭骨 fibrous dysplasia 2 症例につき報告し， monostotic type について若干の文献的考察を加え た.

症例 1 , 男性. 昭和57年 (当時33歳) 頃上り, 両側 耳介前上部腫脹に気付く、昭和 59 年, 両側外耳道狭窑・ 両側難聴・開口障害・耳漏を主訴に当科初診。初診時, 両側鼓膜は観察できなかった。主要検查所見では，血 液生化学・甲状腺機能検查は正常範囲内であった。純 音聴力検㚗は, 両側 $30 \mathrm{~dB} の$ 伝音難聴を認めた。単純 X 線検查では，両側側頭部の淡いスりガラス様陰影を認 め，両側顎関節腔の狭小化をきたしていた，CTでは， 両側側頭骨は全体的に sclerotic な変化をきたしてい た. 中耳構造は保たれて晾り，真珠腫の発生等も認め られず，耳漏は外耳道炎の併発によるものと考えられ た. 右側頭骨からの生検を行い, fibrous dysplasia と 診断した。全身骨シンチグラムで，両側側頭骨・両側 下顎骨・胸骨に強い異常集積を認め，さらに右大腿骨 遠位骨幹・右足関節にも弱い異常集積を認めたため, polyostotic type と考えた。

症例 2 , 女性. 昭和 59 年 (当時43歳) 頃, 左難聴 左耳鳴を自覚し, 近医にて左外耳道狭窄指摘される。 昭和62年当科初診. 初診時, 左鼓膜観察できず，また 本人の自覚は少なかったものの，左側頭部がやや膨隆 し左右差を認めた。主要検査所見では，血液生化学・
甲状腺機能検查に異常を認めなかった，純音聴力検查 では，約 $60 \mathrm{~dB} の$ 伝音難聴を示していた，単純 $\mathrm{X}$ 線検 查では, 異常陰影ははっきりし疗かったが, CTで左側 䕱骨に一致してビマン性のスリガラス様の陰影を認め た。しかし，中耳構造は保たれており，真珠腫等の異 常陰影は認められなかった. 全身骨シンチグラムでは, 左側頭部にのみ異常集積が認められた。左側頭骨の生 検を行い fibrous dysplasia と診断された。本症例は, 左側頭骨のみに病変を有する monostotic type に属す るものと考えられた。

側頭骨の monostotic fibrous dysplasia は比較的ま れで，我々が国内外の文献で娭索し得た限りでは，今 回の症例 2 を含めて33症例を認めたに過ぎなかった。 この33症例をみると，男性が女性の約 2 倍，左右差は 認めず，また20歳までに約70\%が発症していた。しか し，31墄以上の症例も7例認められていた。臨床症状 は，外耳道の狭窄もしくは閉塞・難聴・側頭部の腫脹 が 3 大症状と言われているが，3つともす心゙てそるつ たものは我々の症例を合め15例のみであった．合併症 としては，感音難聴・顔面神経麻疾・真珠腫の発生な どが報告されている，病変の進展範囲の把握や，中耳 から内耳の病態に関してはCTが有用であり, 我々の 症例は, CTにて真珠腫の発生等の所見が認められな かったため，現在外来にて経過䂓察中である。 